\title{
Geography and Mining in Carajás/Pará (Northern Region of Brazil)
}

\author{
João Marcio Palheta da Silva, Christian Nunes da Silva, Clay Anderson Nunes Chagas, \\ Gláucia Rodrigues Nascimento Medeiros \\ Federal University of Pará, (UFPA), Belém, Brazil \\ Email: jmpalheta@ufpa.br, cnunes@ufpa.br, claychagas@yahoo.com.br, glaurn@uol.com.br
}

Received 11 September 2014; revised 8 October 2014; accepted 2 November 2014

Copyright (C) 2014 by authors and Scientific Research Publishing Inc.

This work is licensed under the Creative Commons Attribution International License (CC BY). http://creativecommons.org/licenses/by/4.0/

(c) (i) Open Access

\section{Abstract}

This essay examines the actions of Major Mining Projects in the region of Carajás, the state of Pará, Northern Brazil, which concentrates the projects of one of the largest mining companies of the Planet, the Vale Group, and the relations of power and authority in land use in the corresponding area to the former city of Marabá. The territories exploited by major mining projects, also increase land use that has not been translated into socio-economic development, and add little value to labor and the product. Another issue is lack of a National Mining Policy that truly establishes the regional supply chains, and conducts the multiplier effects to produce new territorial jurisdictions. Mining contributes to socio-economic development of the Amazon region, especially in the Carajás region and promotes the economic organization of the territories for the consolidation of municipalities in which society in its favor uses natural resources. The main objective of this paper is to present the main impacts caused by mining activities in Pará municipalities. Textual elaboration was necessary documentary and bibliographical analysis, in addition to field research in the study area. We can observe, that mining is an important productive activity, but has caused significant changes in Pará territory, both in economy and in the environment, and the way of life of local populations.

\section{Keywords}

Territory, Mining, Amazon, Carajás

\section{Introduction}

The mining territories explored by Major Mining-metallurgical projects in the Amazon have placed the states more and more linked to the international economy, connecting places like eastern Amazon region, which has great potential in mineral resources in dependence on an economy of extraction, transforming the way of life, 
and thinking of local societies and the economy. This activity puts debate on the mining policy and the role played by the State, in setting up a regional development strategy with the purpose of exploiting spatial planning in areas of raw material with low added value to the product and labor.

The importance of mineral resources is due to the fact that they are connecting to strategic and local level to the international level, because of its economic mineral scope of significant economic value in domestic and international markets such as: iron, bauxite, manganese, gold, nickel, copper among others, explored or to be explored. In this context, one of the most important complexes is the mining-metallurgical involving mines in Carajás, of Southeastern Pará. The investments in exploration and the search for minerals become part of the Brazilian Amazon, which is a special area for the country's economic growth, mainly from the 1980s.

The collection of revenue from taxes collected from mining and metallurgical activity is an important source of raising funds by municipal governments to invest in public policy. One of the positives effects for the municipalities, is that under the direct influence of mining projects in the Amazon, especially in the state of Pará, the collection of the Financial Compensation for the Exploitation of Mineral Resources (CFEM), which is an important gauge of financial transfers of investments for municipalities and states, has been forward in terms of economic gains from the projects of the mining companies and its affiliates or contractors, and those who may be virtually deployed in their territories.

Thus, the Brazilian Amazon was related to border expansion of international capital in Latin America. It was the beginning of a new era for the Amazonian states and municipalities and, consequently to Para, the era of ores, which has become the leading economy in the export schedule of the State. Mining companies operating in the state of Pará, such as Vale Group, which was already one of its leading mining companies in Brazil, gained more elements to become one of the largest mining companies in the world, with the potential territorial of projects that explored mineral resources in the State. Therefore, it is necessary to examine the role that mining has on the socioeconomic development of the Amazon region, especially in the Carajás region, where the biggest projects of the Vale group are concentrated in the state of Pará.

One analyzes the power and authority relationships in land use, where the largest mining projects of the Vale Group in Pará are concentrated in the Carajás Region (the area corresponding to the former city of Marabá). They are perceived by their use, relationships and actions between the Vale Group, public and social actors' powers that manifest themselves in the economic organization of the territories and consolidation of municipalities, with new territorial jurisdictions in the region in the period from 2004 to 2014.

The power relations that are formed from the contentious processes in mining depend on the clash with social actors, whether they are the Vale Group, employer's agricultural producers, the landless rural workers, small settlers, homesteaders, individual farmers or corporate, among other prospectors, together with municipal, state and federal powers. All relationships contributing to the territorial management of the Carajás Region, studied here, are differentiated by degree and the complexity of each social actor develops along the political-economicsocial trajectories in their territories, even when sometimes social actors act in more than one municipality.

\section{The Territory of Marabá and Economic Transformation}

Marabá ${ }^{1}$ consolidated its role as a regional center, on the basis of political-economic relations coming from the early twentieth century. With the opening of roads, in the 1960s and 1970s, and mining projects in the 1980s in its territory, the municipality became even more strategic for the development of the State and Country, due to the export of mineral products for the international market and the significant value of its mineral reserves in their territories.

The role played by an elite that maintained power for decades and with it, was consolidated in the field of local government in southeastern Pará, manipulating the political-economic relations, especially to ensure their domains in the region and with that build closer political ties with the capital of Pará, was a way of achieving with confront the crises that ranged from extractive economies of rubber and subsequently Chestnut-nut, that almost always helped to keep the structure of local power; moreover, laid aside the urban and rural problems of their urban cores.

Entrenched political traditionalism by the oligarchic elites and no prospect of improving the living conditions of the populations were exacerbated by social practices that have been consolidated in the area of municipalities for decades such as Marabá. In the absence of a planning view, facing their society, ended up letting through

\footnotetext{
${ }^{1}$ The municipality of Maraba was created 1913, split up of the municipality of São João do Araguaia.
} 
important moments of socioeconomic history and politics of this municipality, causing serious social problems, that are reflected in the current regional settings of the municipalities and power struggles.

The economic cycles (rubber, chestnut) for which the municipality of Marabá and with the emergence of new types of extraction, especially the mineral, has occurred a change in the local power structure: groups of professionals, corporations and banks, began to exercise power in conjunction with the local oligarchy, herein converging, sometimes diverging their interests.

This climate that occurred as from the second half of the 1970s [1], uploaded evidence of the golden age of rubber and Chestnut, in the economic formation in the territory of Marabá, where one can see that the structure of the local oligarchy still exists even though it had rearticulated (facing a new economic model, involving different social actors in the economic conquest of territory) with new social actors, not lose totally the power in the region, through different forms of political favors and unity of local power groups.

\subsection{Mining Projects in Carajás}

The mines of Carajás, in the 1980s, belonged to the territory of Marabá. Therefore, Marabá continued to play a role in pole of southeastern Pará and regional political and economic leader in the Southeast meso-region of the State. The first project to be implemented in Marabá was the Carajás Iron Ore Project (PFC), flagship of the Grande Carajás Program (PGC) ${ }^{2}$ (a package of tax incentives ${ }^{3}$ ), announced in the 1980s, in order to attract investments to the eastern Amazon (relating to agriculture, forestry, livestock and mining-metallurgical sector) and industrialize this territory. In this way, any project that correlated and integrated into this territory would be entitled to tax incentives offered by so-called financial institutions of the State, which in this case was represented by which in this case was represented by the Superintendency for the Development of Amazonia (SUDAM).

For these ventures, it would be necessary to build a whole infrastructure to allocate these projects and to make them work. Therefore, in previous years, since the development axes were traced through the economic feasibility plans for this region and for companies to build there. The Tucuruí Dam is the greatest example of magnificent ambition that one thought in the Brazilian Amazon in order to attract domestic and international capital. The opening of roads in previous years was the first step to fulfill the necessary condition to bring the capital to settle in the Amazon, enabling policies of the Brazilian government.

The overlapping of powers within government bodies served to legitimize acts that were designed for the Amazon region for economic purposes, which, in its turn, explains authoritarianism with which the project was implemented and its complete disassociation with the local reality, contradicting the interests of society that there is located. Consequently, the social and environmental expectations that characterize today Carajás make this region one of the most problematic areas of the country in terms of social conflicts.

It should be emphasized that the Vale Group's other projects outside the southeast mesoregion of Pará, but have remained within the state of Pará, as the exploitation of bauxite by Rio North Mining. The Vale group has a whole apparatus that was mounted by the Federal Government in Para for exploitation of mineral resources, today, are in private hands, as a result of the privatization process of state held by the Federal Government.

The multiplier effect of the Great Carajás Program tend to generate did not materialize; what one sees today in the region, mainly going from Parauapebas in Para to Santa Inês, in Maranhão is a corridor of social problems. Most municipalities lying in the corridor of the Carajás Railroad is experiencing poverty, without expectation of economic growth and unable to solve their urban and rural problems. The passenger train of Vale is a real ship on wheels, with migrants coming and going after work (in projects of the company or in other companies when not in farms located in this stretch) and better living conditions in this corridor.

These factors, above all are related to economic expectations that Brazil lived at the time of installation of the Vale's projects in the Amazon. There were a number of factors that favored the conditions for these projects if they were designed in the Amazon, besides the natural resources that exist in the region. The variables that were used as justification for the implementation of projects in the Amazon were related to conditions of "duplicating Brazilian exports, and thereby, could make more dollars for the payment of Brazil's foreign debt” [2].

These loans have consolidated the viability of PFC and its installation in the municipality of Marabá in the early 1980s, making its first iron ore transport in 1985, with the inauguration of the Carajás Railroad connecting the mines of Carajás in Pará to Itaqui Port in Maranhão. It was the beginning of a new era for the municipalities ${ }^{2}$ Decree law ${ }^{\circ} 1813$ of 24th November 1980.

${ }^{3}$ The fiscal incentives were also regulated by Decree Law $n^{\circ} 1815$ of 24th November 1980, all businesses in an area that encompassed the states of Pará, Tocantins and Maranhão, in total $895.236 \mathrm{Km}^{2}$. 
of southeastern Pará and, consequently, for Pará the era of ores, which became the region's largest economy. Vale, which was already one of the largest mining companies in Brazil, earned more elements to become one of the largest mining companies in the world. This company operates in two prominent systems, the north and south system, which indicated the growth that Vale was gaining with the installation of its projects in Brazil and the Amazon.

The privatization led to the forgetfulness projects taken for granted in Pará, and the change in behavior of the company in relation to the territory in which it operates. Municipalities were only hoping and without any acceptable justification: why priority projects before the State and the company is now in oblivion, and commitments that have been forgotten? One cannot say the same for the municipalities that receive royalties; for the most part the municipalities in southeastern Pará State, that live in precarious conditions and rely on transfers of funds from the federal government and state.

Although it occurs an increase in exports from Pará, this economic growth is not accompanied by the modernization of industry, nor by economic resonance in the municipalities, translated into quality of life for their populations. Nothing guarantees that Pará, an increasingly Miner State (Figure 1), owns and has based only on this type of economy for its development. It is necessary to create development strategies in other scales, such as for example, the agricultural potential of the State.

There is no doubt due to new developments to be installed by Vale, for example, such as Canaã dos Carajás with the Serra do Sossego Mining Project, thus expanding the area under influence of Vale. Further studies should be made to define actually what those areas of the company to benefit those municipalities in Pará. While not defining this question, the Pará State must draw up development goals that address the company as one of its partners, rather than as their enemy, as some politicians, who were always omitted, and when they might interfere with a better definition of the role of the company in Pará territory have done nothing.

The power relations that define spatialized practices both the company and the government need to be revised, in order to create conditions for negotiations between the parties and representatives of civil society. The territory thus becomes a field where different forces act, differentiated practices that constrain social actors in pursuit of their desires. These practices are oppressive to other social actors when they feel harmed by them. The field of power that forms is marked by conflicts of interest, in this case between the company and representatives of civil society.

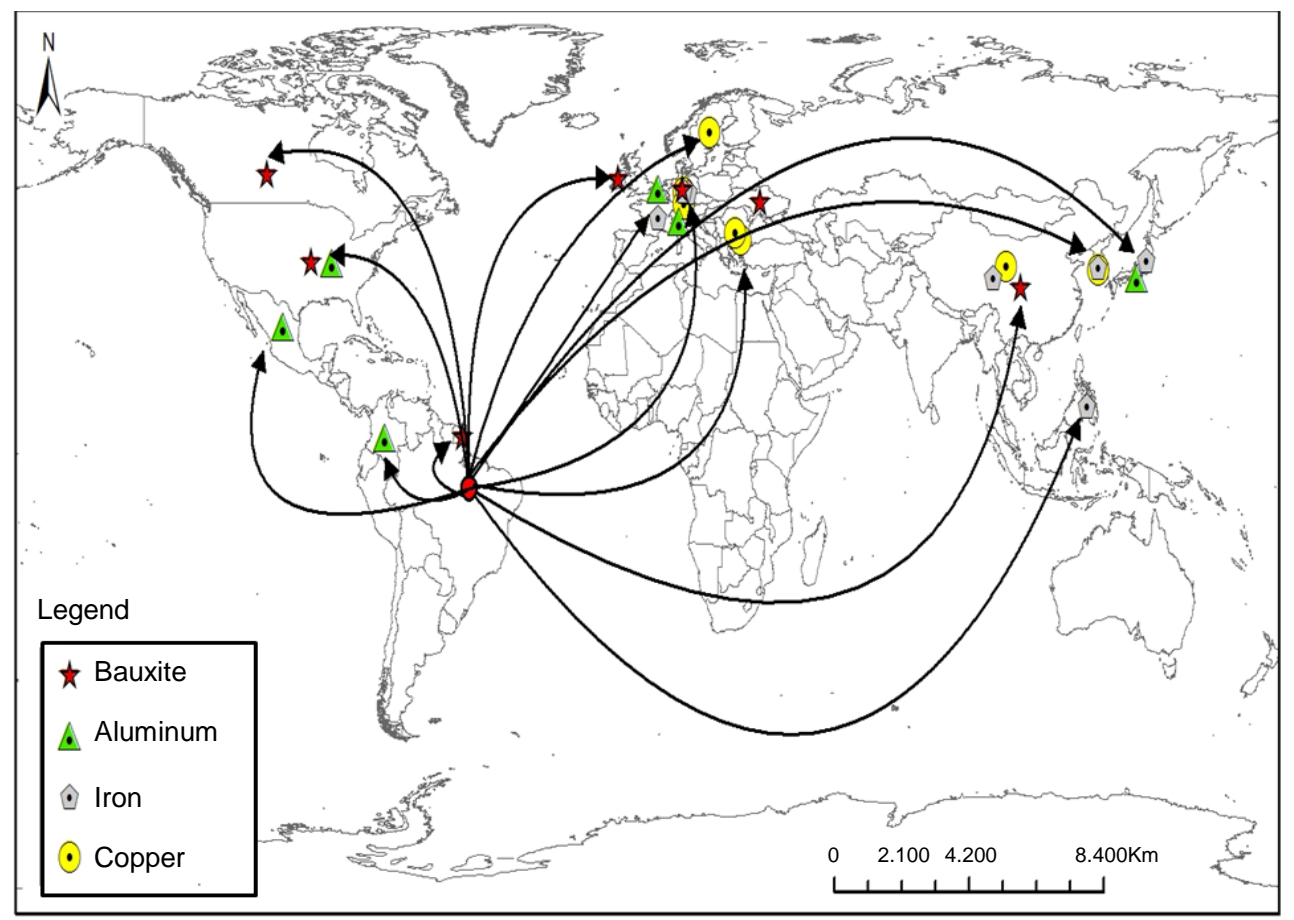

Figure 1. Destination of exports of ores in the state of Pará-bauxite, aluminum, iron and copper (2011 and 2012). (Source: SIMINERAL [3], adapted by the authors). 
The power that the company was gradually conquering exceeded their economic power in the region. Some of their employees or former employees became employees of public authorities in the municipalities in which the company operates, and many others ended up being confused with those who had power within the municipality.

In this case, the order is giving rise to a conflict of interest when observing areas of the municipalities that are under mining area in Carajás. These municipalities are "chosen” by mining companies to perform their projects. Meanwhile other areas, which are potentially virtual for possible projects that do not make directly part of the overall interests of the large corporation, are temporarily excluded from the process of economic organization of the territory. The territorial organization involving other social actors, such as of Carajás, occurs by way of conflict involving different interests and social actors that are not directly related to the mining company.

\subsection{Mining and Municipal Conflict in Carajás}

All questions involving the relations of power and ways to the development of municipalities are still far from being solved, due to different interests of local actors. Parauapebas (broken up from Marabá in 1988) and Canaã dos Carajás (broken up from Parauapebas, in 1994) are still new municipalities, in terms of political and economic emancipation (Figure 2). Like Marabá, these municipalities present old social problems exacerbated by the introduction of mining and plannings carried out without the participation of civil society or rival groups disputing the local power.

Regarding economic and financial issues, the majority of the municipalities in southeast mesoregion of Paráare considered economically poor, with little contribution that depend on the federal government's and have their revenue tied to the question of the Municipalities Participation Fund (FPM). Are municipalities that have total financial dependence that end up burdening other cities for not having sufficient infrastructure to meet its population, seeking better services at other nearby locations, and also end up migrating to municipalities like Parauapebas or to Marabá. The latter receive problems to be resolved in adjacent municipalities.

In Pará's municipalities, the prefectures are often the main employers. Without prospect of attracting industries and services, these municipalities give their future in terms of economic development, to the wishes of projects that could or are deployed, in case of the region of Carajás, by the Vale Group. Another highlight is related to the dependency that municipalities have around the mining activities, the monopoly of the exploitation of minerals in the region is a factor that prevents competition for the best projects and actions by other companies, since Vale controls hegemonic the operation of the main minerals in the region.

In interviews with representatives of civil society organizations, was almost unanimous with the necessity of

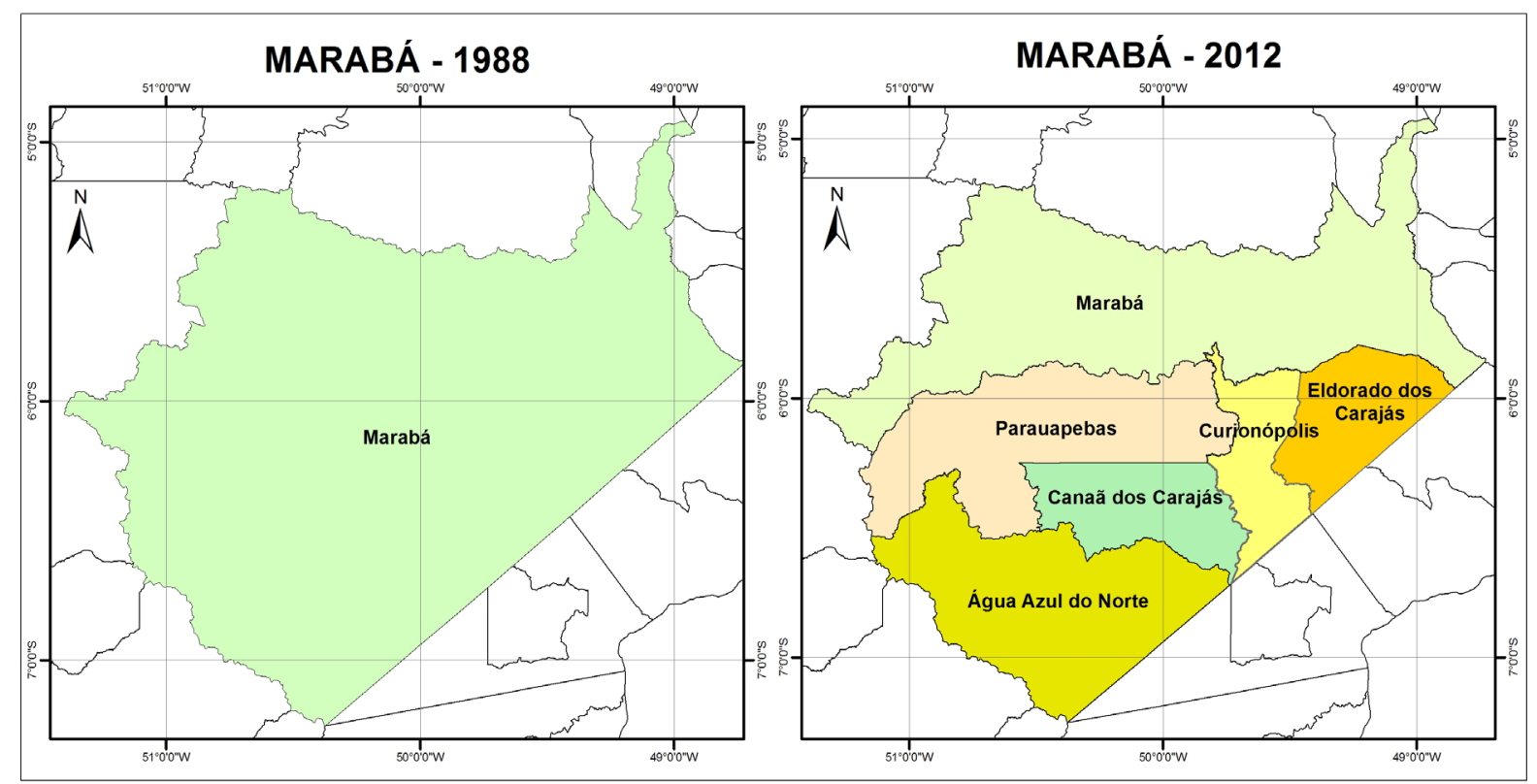

Figure 2. Area of Marabá’s former city. (Source: elaborated by the authors). 
opening the south and southeast Pará other companies to conduct their surveys. Other companies need to share with the Vale Group's economic and social responsibility for the development of projects. It is believed that the only way there will be a redistribution of economic power by virtue of breaking the monopoly exercised by Vale in the region, and in conjunction with other power changes, it becomes possible to other land use than the current model for mineral exploration, that adds little value to the product and labor becoming dependent on the region and has led to the impoverishment of mining cities [4].

According to statements, collected in the region it is impossible to negotiate with a single company issue of social interests. With other companies present at the municipality, necessarily, a dispute occurs to see who best takes a leading role, both in the economic sector, as regards the social in the municipalities. Thereby will grow the number of future projects, in a way that could actually happen to vertical integration of production within the territory of Para. For this, one must also avoid leakage there projects for beneficiation of ores elsewhere outside the State of Pará this is a national issue, which unfortunately has not been treated with due importance, due to the strategic development of any nation natural resources.

To try to change this situation, considered critical not only in relation to the government, but due to the activities developed by Vale Group that has impacted some municipalities that do not have in their territories company projects, or those that can accommodate future projects of it, creating an alternative, increase the rate of royalties to try to mitigate the social and economic problems, both for those having projects, as for those who end up suffering influences of these projects. But this is a stopgap solution as forms of wealth distribution remain the same, but there is transparency in the distribution of proceeds from mining. Contributing to this lack of a national policy that favors mining uprighting, to complete the production chain or part thereof, to add more value to the product and work in the region, creating a multiplier effect.

It is necessary a political agenda with all stakeholders to democratize the actions and processes making, above all, democratized the information of society, to decide on the mineral exploration in the region And not increase poverty that prevails in the area in which occur Major Mining Projects, namely, those municipalities that receive, and others who do not receive benefits from mineral exploration.

According to local representatives, differently from other municipalities, for example, Parauapebas ends up being the center of the microregion, by having the main activities do oth the Vale Group. According to some representatives of local trade, Canaã is a film of Parauapebas, is a movie that happened here, and is passing there, a boom in employment, a city that for years had 13 thousand inhabitants, and hand labor for the project generated was 30,000. It was a construction site from here to there, Parauapebas was that. Parauapebas will remain the center of this microregion.

For other representatives of trade and industry, will have no other way; with the end of the first stage of major projects, a reverse migration occurs towards the cities with better infrastructure and employment opportunities, as is the case of Parauapebas, the main and closest city with better infrastructure than Canaã. For this reason, believe that those migrants who are going for jobs will end up in Parauapebas. Not everyone will get jobs in Canaã, and Parauapebas is the most appropriate place to try their luck, this according to them, also contributes to land use in the vicinity of the mining towns without the municipal planning.

\subsection{CFEM as an Instrument of Spatial Planning}

Concerning the Financial Contribution on Mineral Exploration (CFEM), the state of Pará, together with the State of Minas Gerais, accounted in 1999 for $73 \%$ of its revenues, being respectively $31.7 \%$ and $41.4 \%$ levies of the Country. The criticism rests on the experience of Parauapebas, receiving the resource (the city received in 997 $\mathrm{R} \$ 1,195,493,007$ and 1998 received $\mathrm{R} \$ 1,439,461,485$ and in 1999 received $\mathrm{R} \$ 1,532,645,545$ of CFEM, by owning the Vale projects in their municipality (Figure 3), although the municipality itself presents serious social problems, as health and infrastructure in some more distant neighborhoods, as is the case of Liberdade neighborhood, in contrast with the pioneering nucleus of the city, that received investment of Vale at the beginning of the deployment of Iron Ore Project.

Since these municipalities in its territory that have mining projects receiving many migrants, Vale needs along with the Union, the state and the municipality think about this question [7]. While it is not the function of company, these issues are part of their vicarious liability due to the metamorphosis that occurred in the last two decades of the twentieth century and the first of the twenty-first century. One needs to rethink the issue of mining in Pará, by setting, especially the area that is under the influence of the Vale Group and apply resources to minimize 


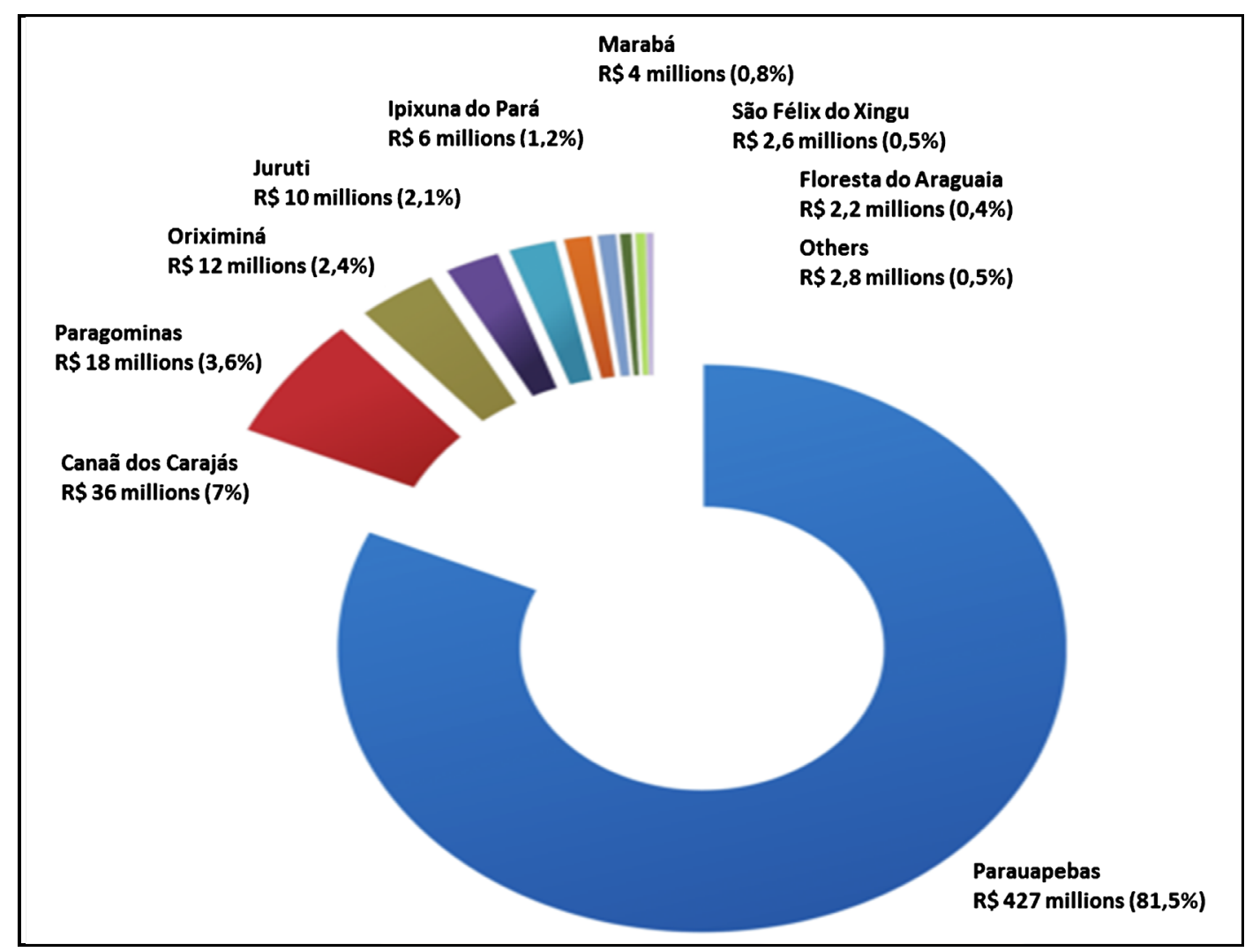

Figure 3. Collection of the CFEM by municipality in the state of Pará (2011). (Source: [5] [6]).

these problems, differently from how it was at the time the Compensation Fund of Areas of Influence of Vale.

There is lack of database with socioeconomic indicators, common in all the municipalities studied in this research, and one has not yet defined what would be the axis of development in these municipalities. This facilitates domain actions as are inherent of Vale in the region, which fragments the power relations within the municipality, leaving no space for new ideas with regard to economic and social policies outlined in the medium and long term for the municipality.

Another question related to increased rates of CFEM, that many politicians believe to be the salvation of the territories that have mineral resources, must go beyond the increase in the rate and distribution and include a discussion involving all civil society and public authorities with the mining companies [8], on what are the areas under the influence of Vale in Pará, and how these resources would be applied to spatial planning.

The questions raised by some politicians these municipalities, among them which house projects of the Vale Group, is related to the lifetime of mining projects, especially those related to Copper, that is short-lived, and warning about potential problems especially migratory, of people attracted by the false illusion of regional development that occurs in Pará, without the resolution of conflicts and old problems such as those related, especially the land issue in the region.

\section{Power Relations and the Issue of Territory}

Given the political fact and others, such as economic, the residents feel harmed by the various municipal governments that alternated in power. According to them "the proposals of the prefectures were not proposed, were imposed; the relationship of dialogue between the government and of society in this sense does not exist in the city"4. Thus, the rhetoric of some representatives of organized civil society is to make the city a public space promoted by popular participation.

Another important point is related to the government that dominated the city for years, who had inhibiting the

${ }^{4}$ Field work, 2004/2012. 
entry of other industries to compete, especially with Vale [9]. But according to testimony from representatives of civil society, Vale itself will not give up its deposits or part which contemplates, mainly the Carajás National Forest. According to them, Vale feels threatened by the possible exploitation of the forest by other companies, which are not part of it.

In one way or another, the important thing is that one has to rethink the role of mining in Pará and companies such as Vale, that operate within the state, and the multiplier effect that was generated by these projects in the Amazon. The issue of increasing the tax rate has to be accompanied by a new way of thinking about development in the region, which takes into account the local society and the impacts generated by these projects. One must not repeat the mistakes of the past, not just the quantification, but in qualifying the application of these resources, and not allow companies assemble their infrastructure out of the state, this being only as the supplier of the raw material.

Issues relating to mining cities are questions that run through their economic viability and the ability of each of the training resources to enable, both the planning and the municipal development. The relationship of economic feasibility in mining cities is very distinct.

\section{Conclusions}

The multiplicity of phenomena throughout Para's history accelerated socio-spatial transformations, and was not accompanied by public policies that addressed the immediate short, medium and long term of the Amazonian societies, which in turn created processes of poverty by ensuring their permanence, socio-economic and cultural regions where large projects were installed, as the case of Carajás.

The corridors or axes of development in Para follow their own logic of territorial organization, which responds to the interests of local and international economic elites, conflicting with the interests of companies that are mostly victims of the capitalization process in the Amazon by the large mining capital, connected internationally by the strategic value, having its mineral resources in the world-economy.

The international economic interests contrast with local poverty. The Amazon in Pará, rich in minerals and other natural resources, coexists with almost complete abandonment of lawful order for the state to maintain their societies. To ensure their permanence on the territory is a challenge on itself, because civil society has its own socio-economic and cultural viability in the Pará region.

It is of great importance to ensure that the traditional people and the entire society, living in the Amazon, not only use their direct natural resources, as the rest of humanity does. These respect their particularities, as well as their right to choose forms of integration and socioeconomic development.

The multiplicity of actors who are fighting for their various rights tends to intensify control and struggles for possession and use of natural resources essential for the development of Amazonian society. Nowadays, in the Amazon of the XXI century, ancient mistakes affect our past history of impunity and disregard Amazonian peoples, namely, land conflicts between various social actors and the simultaneous major capital, on the contrary to the large mining companies and the agribusiness, which without proper planning of social order end up disregarding the economic potential and characteristics of Amazonian communities.

The great challenge in the forms of use of natural resources in the Amazon is the way to no longer commit the mistakes of the past. It is no longer possible to occupy the forest with predatory activities, such as agropastoral, logging and indiscriminate exploration of mineral resources. In this form, the use and processing of mineral resources has been conducted in the Amazon, being irrational for local companies. The activities can change only their fast pace with no multiplier effects, increasing particularly the region by means of exploitation of resources and regional economic dynamics, in turn for regional wealth and poverty.

How to ensure a national project for the use of mineral resources if the control and absence of the state are nearly complete in the Amazon, especially in the state of Pará? Municipalities rich in minerals contrast with local poverty. Absence of legal channels that allow the participation of organized civil society prevails in most localities from Pará. If land use policies are built without the effective participation of civil society, we have nothing of novelty, but the legitimacy of the process of extermination of human and natural resources, inciting further conflict in the region and in the state of Pará with the lack of participation of the company.

\section{Funding}

This research was funded by the Qualified Publication Support Program (PAPQ), offered by the Dean of Re- 
search and Graduate Studies (PROPESP) and the Foundation for the Support and Development of Research (FADESP), of the Federal University of Pará.

This essay is part of the research project "Use of the territory and Socio-Environmental Impacts of mining and metallurgical activities in the municipalities of Parauapebas and Juruti, in the state of Pará" with funding from the National Council for Scientific and Technological Development-CNPq.

\section{References}

[1] Emmi, M.F. (1988) A oligarquia do Tocantins e o domínio dos castanhais. NAEA/UFPA, Belém.

[2] Benatti, J.H. (1997) Carajás: Desenvolvimento ou destruição? In: Coelho, M.C.N. and Cota, R.G., Eds., 10 anos da estrada de ferro Carajás, NAEA/UFPA, Belém, 79-106.

[3] Sindicato, das Indústrias Minerais do Estado do Pará—SIMINERAL (2013) Anuário Mineral do Pará. Sindicato das Indústrias Minerais do Estado do Pará, Belém.

[4] da Silva, J.M.P. (2013) Território e Mineração em Carajás. GAPTA/UFPA, Belém.

[5] DNPM, Departamento, Nacional de Produção Mineral (2010) Anuário mineral brasileiro. DNPM, Brasília.

[6] DNPM, Departamento, Nacional de Produção Mineral (2011) Sumário Mineral/MME. DNPM/DIPLAM, Brasília.

[7] da Silva, J.M.P. (2004) Poder, governo e território em Carajás. PhD Thesis, FCT/UNESP, Presidente Prudente, São Paulo.

[8] Ibram, Instituto Brasileiro de mineração (2011) Indústria da mineração. Ano VI, No. 41. FIPE/SETRAN, MME, Brasília.

[9] Coelho, M.C.N. (2011) Sócio-Economic Impacts of the Carajás Railroad in Maranhão—Brasil. PhD Thesis, Syracuse University, Syracuse (USA). 
Scientific Research Publishing (SCIRP) is one of the largest Open Access journal publishers. It is currently publishing more than 200 open access, online, peer-reviewed journals covering a wide range of academic disciplines. SCIRP serves the worldwide academic communities and contributes to the progress and application of science with its publication.

Other selected journals from SCIRP are listed as below. Submit your manuscript to us via either submit@scirp.org or Online Submission Portal.
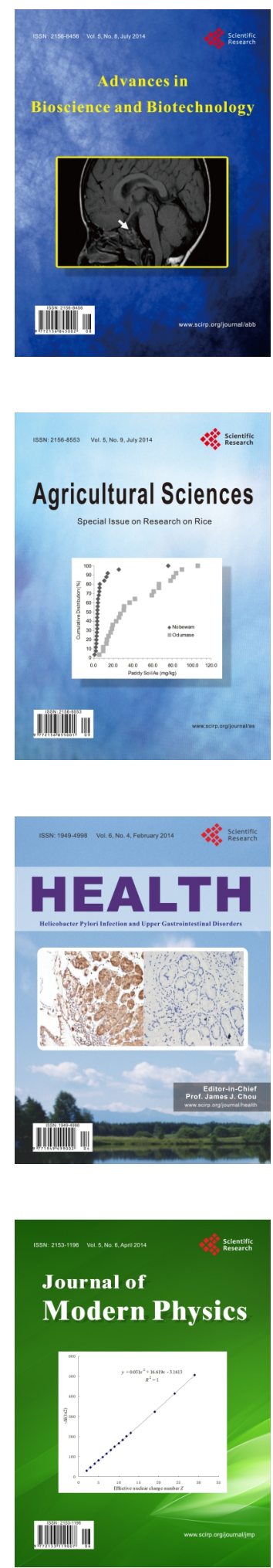
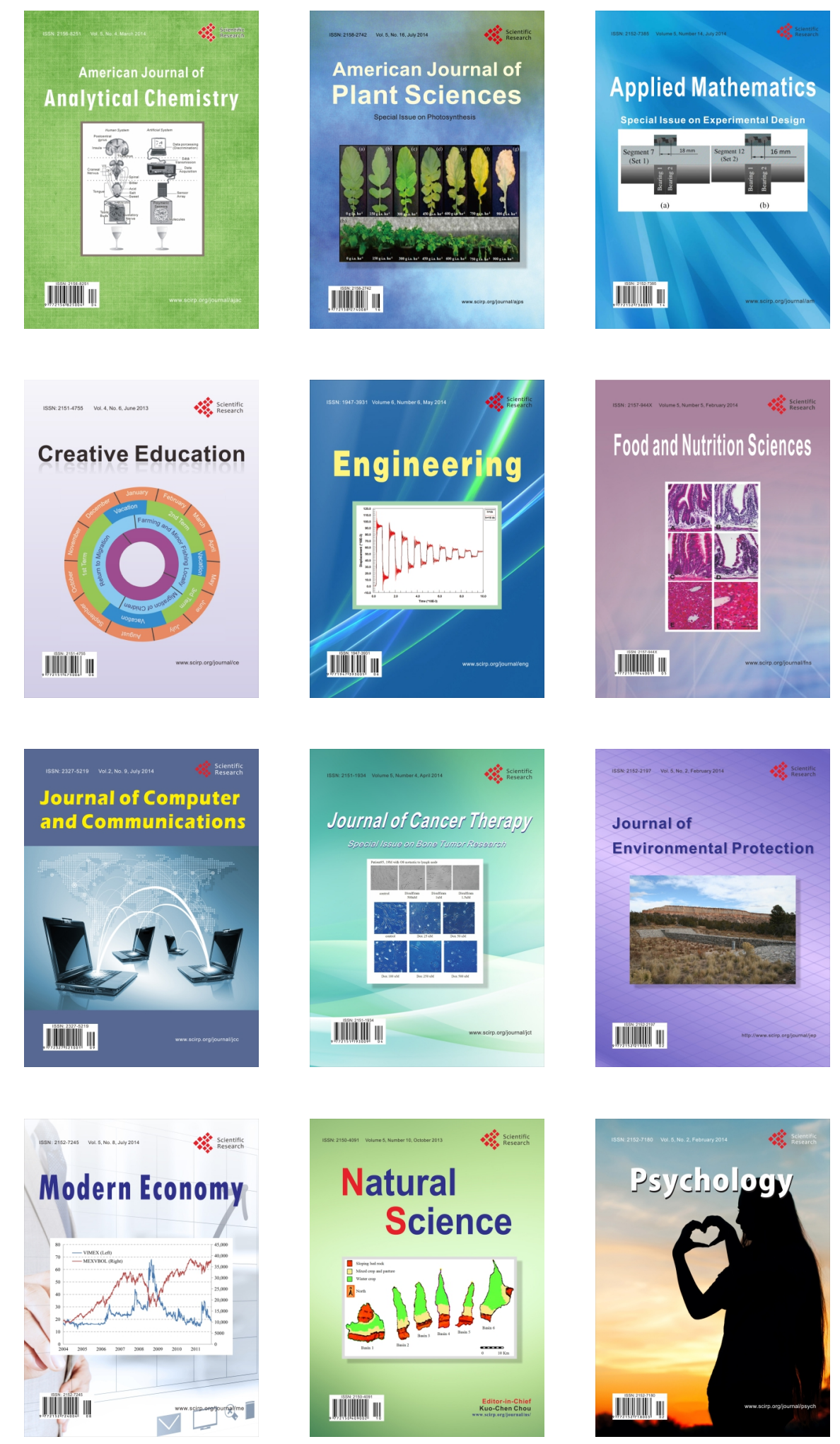